\title{
СПІВВІДНОШЕННЯ ІСТОРИЧНОЇ І ХУДОЖНЬОЇ ПРАВДИ В КОЗАЦЬКОМУ ПІСЕННОМУ ФОЛЬКЛОРІ НАДДНІПРЯНЩИНИ
}

Козаџький фольклор Наддніпрянщини розглядається як иілісна жанровотематична система в плані методології вивчення домінуючих ознак ії поетики, естетики, конщепиії героя, структури тексту. Під кутом зору проблеми історичної та художньої правди з'ясовується ступінь вірогідності зображених подій козаччини в українському пісенному фольклорі, обумовлено в якій мірі козачький фольклор є історичним джерелом.

Ключові слова: козацький пісенний фольклор, жанр, козаччина.

Казачкий фольклор Надднипрянщины рассматривается как иелостная жанрово-тематическая система в плане методологии изучения доминирующих признаков ее поэтики, конщепщии героя, структуры текста. Под углом зрения проблемы исторической и художественной правды выясняется степень вероятности изображения событий казатчины в украинском песенном фольклоре, обусловлено в какой мере казаикий фольклор является историческим источником.

Ключевые слова: казаикий песенный фольклор, жанр, казатчина.

This article for the first time describes artistic and Cossack folklore of center and lower parts of the Dnipro banks of the as integral genre-thematic system is in the plan of methodology of study of dominant signs of its poetics, aesthetics, conception of hero, structure of text. It is defined that it is a degree of authenticity of zobrazhennikh events of the Cossacks in Ukrainian folklore, in what measure Cossack folklore is a historical source.

Key words: cossack folklore, the cossacks, genre.

Відомо, що фольклор не є документальним літописом історичних подій, однак він залишається невідступним і своєрідним супутником історії людства. Український фольклор часів козаччини є «...історичним свідченням зрілості нації, ї̈ здатності відчу- 
вати своє місие у всесвітній історій, утверджувати своє майбутнє» [Яременко 1970: 8], належить до світових шедеврів мистецтва.

Козацький пісенний фольклор Наддніпрянщини досліджувався з історичного погляду в працях М.Цертелєва, М.Максимовича, М.Гоголя, І.Срезнєвського, М.Костомарова, П.Куліша, М.Драгоманова, М.Сумцова, А.Кримського, І.Франка, П.Житецького, П.Мартиновича, Ф.Колесси, М.Грушевського, К.Грушевської, Я.Новицького, Д.Яворницького. Частково ця тема реалізована в фольклористичних студіях М.Рильського, Б.Кирдана, О.Дея, Б.Путілова, С.Грици, В.Буряка, Ф.Кейди.

Наша ціль зводиться до того, щоб під кутом зору проблеми історичної та художньої правди проаналізувати пісенні жанри козацького фольклору, з'ясувати ступінь вірогідності зображених подій козаччини, іiї героїв; встановити за допомогою яких художніх прийомів, засобів відображається історична дійсність в козацькому пісенному фольклорі.

Козацький фольклор Наддніпрянщини становить цілісну жанрово - тематичну систему, яка виникла, розвивалася та ефективно функціонувала на території українських земель упродовж XV-XVIII ст. Це був найпродуктивніший період для ліричних (козацькі пісні), епічних (героїчні легенди, перекази, оповіді-спогади, казки, анекдоти), ліро-епічних (думи, балади, історичні пісні, пісні-хроніки) творів. І хоча ці фольклорні твори неоднорідні за характером художнього відображення реальних подій, тобто порізному відображають історичну дійсність, все ж вони чи не найбільшою мірою зафіксували весь обсяг періоду козацької доби, а саме: безперервну боротьбу запорозького козацтва із іноземними загарбниками українських земель у XV-XVIIIст.; визначили ставлення самого народу до історичних подій, осіб і обставин періоду виникнення на наддніпрянській землі Запорозької Січі, іiі учасників та очевидців.

Історична основа українського козацького фольклору представлена узагальнено реальними подіями з участю реальних пер- 
сонажів. Це означає, що керуючись формальною логікою, відтворена дійсність вочевидь є правдоподібною і достовірною. При цьому кожен жанр козацького фольклору характеризується особливим відношенням до дійсності та способом художнього відображення не лише історичних подій, народного побуту, сімейнопобутових, суспільно-політичних відносин, але й проявом характеру, світогляду героїв козацької доби.

Для пісенних жанрів козацького фольклору XV-XVIII ст. характерні ліричний, епічний та драматичний способи відображення дійсності.

Виникнувши на основі народної традиції Наддніпрянщини, козацькі пісні не лише успадкували від обрядової лірики, родиннообрядової та епічної пісенності провідні ознаки тематики та поетики, а й витворили типового представника Запорозької Січі ліричний образ козака, поява якого була спричинена історичною ситуацією, що склалася в XV-XVI ст. в Україні під гнітом чужоземних загарбників. Їх військовий спосіб життя зумовив виникнення своєрідної пісенності, що задовольняла естетичні смаки самих козаків, розповідала про типові моменти козацької обрядовості, представила світогляд козаків, возвеличила їх смерть. Так, у козацьких піснях історичне зображення воїна, розкриття його почуттів, переживань, роздумів, духовного світу не обходиться без ліризму. Формульні елементи міфологічного та раннього історичного змісту у сюжетах козацьких пісень часто вказують на ліро-епічну природу жанру. Ці пісні вражають яскравістю історичної правди про долю козака $з$ позицій національного світосприймання, народної моралі, етики та естетики козацького братства. Це пісні про польову сторожу, постій козаків, пожежу в степу, бурю на морі й потоплення турецького корабля, про поєдинки з турками і татарами; прощання козака $з$ рідними та його від’їд 3 дому; про небезпеки, на які постійно наражалися козаки; про від’їзд козака на чужину; про ностальгію, що посилюється мотивом самотності козака на чужині; про визволення козака з полону; набір новобранців до 
війська; смерть козака на полі бою; про кохання дівчини до козака; про побачення, закоханість, залицяння козака до дівчини та розлучення через наговори; про нещасливе кохання між козаком і дівчиною; коли козак підмовляв та викрадав дівчину; про смерть козака на «земляних, канальських роботах»; про ностальгію за втраченою козацькою волею. Художнє відтворення реально суворого козацького життя, як правило, відзначається драматизмом. Особливим драматизмом перейняті козацькі пісні, що пояснюють світоглядні вірування козаків, визначають їх ставлення до долі, волі. Вони зумовлені особливістю степового ландшафту земель Наддніпрянщини. Так, козак баче в навколишніх предметах не лише безжиттєву матерію, а й зв'язок який об'єднує цю матерію з духовним створінням. У козацькій пісні «Не жур мене, моя мати» козак сумує за волею, щчо уособлена в образах вітру, поля: «В чистім полі тирса шумить, / Катран зеленіє, / В чистім полі своя воля, / Що й серие німіє» [СПП 1985: 78]. Формули пісенного паралелізму, що побудовані на асоціаціях та зіставленні психічного стану людини 3 символічними картинами природи є визначальним у розгортанні сюжету більшості козацьких пісень, серед яких: «Туман поле покриває», «Гей, з устні Дніпра та до вериини», «Добривечір тобі, зелена діброво» [СПП 1985: 39-40]. Поряд із історичними фактами про кочове життя, побут воїна, козацька пісенна лірика представила міфологічно-романтизований образ козака, що містить у собі рудименти сонячного божества, потойбічного змія та сакрального предка-символу, а також міфологічні мотиви та романтичні аспекти образотворення: розмова козака з Дніпром, змагання між конем і орлом, розмова сокола з орлом над загиблим козаком; надзвичайна чуттєвість козака, його надприродні можливості, дух нездоланності та волі. Ці мотиви передано через персоніфіковані сили природи: образи степу, вітру, могили; рослинні образи калини, дуба, ялини, явора, берези; зооморфні образи коня, сокола, орла, зозулі, голубки, ластівки. Якщо образ сокола, орла, ворона символізує смерть козака, то образи зозулі, голубки, ластівки уособлюють 
рідних і близьких героя. І хоча такий підхід є умовний, бо в одному й тому ж творі переплітаються різноманітні мотиви історичних епох, все ж він дозволяє встановити, що за символічно-метафоричною образністю, героїчним та емоційно-драматичним ставленням до подій і явищ військового життя, козацькі пісні споріднені 3 билинами, історичними піснями, думами, баладами; поетична традиція яких базується на мотивах героїчного епосу княжого періоду.

Історична основа козацьких балад проявилася в тому, що в них представлені драматичні події часів козаччини. Козаків переповнювали пристрасті і переживання, в найтрагічніші моменти для історії України. У баладах більше психологічно напружених моментів із життя козаків, які обумовлюють їх риси характеру та вчинки. Існує ряд козацьких балад, які стосуються власне представників козацької вольності. I хоча переважно подано імена, які не тільки слабо індивідуалізовані, але й випадково або досить механічно причеплені до історично-побутових типів і картин, та все ж не позбавлені реальної життєвої основи. Це - балада про Байду в турецькому полоні, про поєдинок Нечая з шляхетським загоном, про страту гайдамаками зрадника Сави Чалого. Так, у козацькій баладі «У Цариграді на риночку», - записаній у середині XIX cm. оспівано подвиг Байди - полум'яного патріота рідної землі, бория проти турецького поневолення. М.Костомаров із захопленням відгукувався про иеей твір, оскільки «ия пісня про події XVI cm. ранішніх часів козаччини одна тільки збереглася і дійшла до нас...» [ Костомаров 1880: 43], бо в ній відтворено оповідь про князя Дмитра Вишневецького, одного із перших провідників козацтва, який у 50-роках XVI ст. на острові Хортиця поставив замок для боротьби проти кримської орди. Він справляв величезне враження на сучасників, але його героїчна смерть у 1563 році перевищила і затемнила багатий зміст його бурхливого життя. «Його смерть, - як визначав М.Возняк, - стала джерелом легенд. Оповідали, що він закінчив своє життя, повішений на гак за ребро в Царгороді й, висячи так три дні, насміхався 3 турків і лаяв Магомета, внаслідок чого 
турки його застрелили. 3 подиву для його відваги й завзяття турки розділили поміж себе та їли його, щоб і собі присвоїти щось із його сміливості та зневаги до смерті. Оповідали, що сам султан, здивований хоробрістю й подвигами Вишневецького, хотів зробити з нього турка, обіцяючи йому всякі ласки й добра, але він зневажав те все й вибрав страшну смерть замість панування в бусурманів. Висячи на гаку, попросив лука та стріл, жертвою яких упали турки та сам султан. Було б дивно, якби такі поетичні оповідання не діждалися пісенної обробки»[Возняк 1994: 445-446]. Можливо, що саме цей факт посприяв виникненню балади серед козаків, бо «...в цій людині було те, що завжди подобалося козакам; він не дуже слухався верховної влади і не дуже дорожив цією милістю до себе, самовільно ходив воювати, самовільно вступав на службу до московського царя і самовільно залишив іiі...

Д. Вишневецький був більше козак, ніж пан, бо ж ніяк не був схожим він на такого пана, якого тип став козаком ненависним в образі пана - ляха[ Костомаров 1880: 43]. У баладі Байда виявляє твердість духу і несхитну відданість рідній вірі, що на той час було рівнозначним вірності українській нації. Картина розправи Байди 3 ворогами стверджує провідну думку твору: козак за будь-яких обставин повинен лишатися патріотом свого краю. Ніякі знущання і тортури не похитнули цих почувань, а відтак, народ, який уміє захищати волю і незалежність своєї країни - безсмертний. Отже, загибель Байди була перемогою могутнього козацького духу над грубою фізичною силою ворога.

Творче відображення історичної дійсності не виключало взаємодії історичних подій з вигаданими сюжетами про палкого патріота, який не скоряється ворогам, бореться проти соціальної несправедливості. Таким є образ Морозенка у козацькій баладі «Ой Морозе, Морозенку», записаній у 1834p. М. Максимовичем. Уже 3 перших рядків твору перед нами постає мудрий і відважний лицар, оборонець рідного краю, який своєю діяльністю зажив слави по всій Україні: «Попереду Морозенко сивим конем грає». Ні стра- 
ху, ні втоми не знав славний герой у боротьбі з ворогами. Не схитнувшись, він приймає і страшну кару за свою Україну. Витривалість Морозенка відповідає законам художнього відтворення дійсності, базується на достовірних фактах розправи степових хижаків над захопленими жертвами.

Тематика козацьких балад пов'язана 3 історичними реаліями того часу, в них піднімаються проблеми загарбницьких війн і їх наслідків. Найпоширеніші баладні мотиви - проводи козака на війну 3 магічним провіщенням його загибелі; смерть козака внаслідок драматичного збігу обставин, незвичайних подій; рабство як наслідок турецьких набігів і драматичні долі козаків в полоні. У козацьких баладах більш пізнього періоду вже немає нічого містичного, надприродного чи магічного, їх напруженість і драматизм витікає із незвичайної, але реальної соціально-побутової ситуації, в яку потрапляє козак і єдиним виходом з якої часто є смерть. М.Костомаров пояснював, що саме опис смерті козака в степу «повинен був зробитися любим образом в народній пісенності. Такі образи були милі серцю і уяві багатьох. Батьки згадували своїх дітей, які не повернулися із степів i, багато в Україні було жінок, які залишили в степах своїх чоловіків і братів, або томилися незнанням про їх долю, після того як вони, залишивши свій дім, відправились на степові вчинки. Від таких сердечних порухів лилися ці сумні пісні, частіше складені на старій підкладі, засвоєної несвідомо од минулих поколінь» [Костомаров 1880: 71]. Такими були козацькі думи про отамана Безродного; про трьох братів, які втекли 3 Азова; про жінку кошового отамана Сірка і двох його синів; про смерть козака на долині Кодеми; а також пісні про Морозенка, Супруна, Головатого. На думку Ф.Колесси, дума як козацький епос виник «по всякій правдоподібності серед козачтвва, на підкладі воєнного козаџького життя і призначені головно для козащької аудиторї̈»[Колесса 1935: 60]. Збережені думи на території Наддніпрянщини присвячені подіям та історичним випадкам козаччини пізнішої доби, коли вона була організованою воєнною 
силою, що підіймала сміливі походи на суші й морі. Ці думи змальовують події й постаті козацьких діячів, представляють образи мужніх, благородних і сильних духом героїв. При цьому «в думах видно думки й почування самого співака: епічне оповідання проривається виливом почувань ліричної пісні або закінчується сумними роздумуваннями, апострофами й молитовними закликами... Настрій думи, себто становище, з якого поет дивиться на предмет своєї поезії, дуже поважний і врочистий» [Возняк 1994: 436].

Розвитку і поглибленню народнопоетичного зображення образу козака сприяло відтворення реальних осіб козаччини в історичних піснях. Історична пісня часів козаччини виростала на грунті всього народнопоетичного досвіду етносів Наддніпрянщини, засвідчуючи при цьому нову, вищу ступінь історичної свідомості козацького народу. М.Костомаров у своїй праці «Історія козацтва в пам'ятниках південноруської народної пісенної творчості» (1880) визнавав, що народну поезію козаччини слід класифікувати відносно історичних явищ. На підставі чого виділяв такі цикли і розділи: «1.Боротьба козацтва 3 магометанським світом. Вона виразилась: а) низкою козацьких походів на Чорне море, котрі були наслідками набігів на приморські турецькі міста; б) зіткнення козаків 3 кримськими, ногайськими, буджацькими татарами в степах; в) напад мусульман на житлові місцевості Південної Русі. 2. Боротьба південно-руського народу з Польщею. 3. Внутрішні суспільні явища, які виникли внаслідок боротьби з Польщею» [Костомаров 1880: 1]. Також вчений вирізняв козацьку поезію, яка виникала під час степових і морських походів. На його думку, «в малоруській народній поезії є иіла група дум і пісень, щуо зображують степові битви $i$ сутички козаків з татарами, та смерть козака в степу. Деякі із цих пісень - з власними іменами козацьких богатирів, інші ж без власних імен, з єдиним узагальненим - козак, але взагалі, $і$ там, де є власне ім'я, складно буває зміст пісні приурочити до тої чи іншої події та до часу. Пісні иі, звісно, для історії важливіші, по зображенню побутових рис минулого життя, ніж по вираженню 
народних поглядів, ніж по відношенню до фізичної правди» [Костомаров 1880: 44]. У циклі козацької поезії про морські походи «народна пам'ять не завжди сходиться з писаною історією. Багато такого, шуо прославлено істориками, лишається для народу невідомим, і про багатьох, кого народ прославляє, важко буває докопатися в писаних історичних матеріалах» [Костомаров 1880: 2]. На підтвердження М.Костомаров подає аналіз думи про Олексія Поповича. Ймовірно, що козацькі думи, як історичні пісні українського народу - особливо на ранніх етапах розвитку - чимало запозичили 3 поетики, стилю, творчої манери давньоруських героїчних колядок, оскільки елементи історизму зустрічаються у героїчних колядках, у яких оспівувався бій воїна-русича 3 ворогомчужинцем (печенігом, турком). Проте вже козацький епос Хмельниччини має свої особливості: героями цих творів стали не вигадані, а реально існуючі історичні постаті патріотичного поривання і обов'язку. Особливе місце відведено гетьману Богдану Хмельницькому. Його образ є провідним у всіх легендах, переказах, піснях та думах цього історичного періоду. Козак-творець і виконавець, що був очевидцем та безпосереднім учасником бурхливих історичних події, що швидко розвивалися не завжди міг передати їх у традиційних пісенних канонах, тому в них відчутний вплив та перевага авторських віршів історичного змісту над впливом традиційних фольклорних формул. Це стосується, в першу чергу, прославлення героїчних вчинків достовірних осіб Хмельницького, Кривоноса, Нечая, Богуна, за віддане служіння батьківщині, бо «дійсність, охоплена історичною піснею, включає сферу історичного життя народу, життя політичного, як внутрішнього, так і зовнішнього. Народ не тільки відтворює події, але і дає їм свою оцінку» [Пропп 1998: 229]. Ці твори поширені по всій Україні (особливо в Полтавській, Київській, Дніпропетровській, Кіровоградській областях), та за іiі межами (Польща, Угорщина, Росія, Молдавія). Це було зумовлено конкретними історичними подіями національно-визвольної війни XVII ст., яка вказала на те, що український 
народ виступає активно, є творцем своєї долі й життя, зривається до боротьби на смерть за здійснення своїх мрій і бажань. Так, запорукою перемог і безсмертної слави Б.Хмельницького $є$ його боротьба за рідну землю, за волю для свого народу. Про це пісні «Чи не той то Хміль», «Засвистали козаченьки», «Не дивуйтеся, добрі люди», «Ой, 3 города 3 Немирова». В основі цих творів історичні факти: перемога козаків у битві під Жовтими Водами, під Корсунем, в районі Жванця Хмельницької області. Козаки ідеалізують гетьмана, плекають серед народу культ Хмельницького як мудрого державного діяча: «Гей, поїхав Хмельницький к Золотому Броду, - / Гей, не один лях лежить / Головою в воду» [УНД 1955: 92] $]^{1}$. Така ідеалізація відповідає природі фольклору, бо це дозволяло козакам моделювати образ народного ватажка, тобто наділити його рисами, які він хотів би бачити в своєму улюбленому героєві. I щоб підсилити його зв'язок з народом, творці історичних пісень вдаються не лише до ідеалізації, а й конкретизації та деталізації вчинків Богдана Хмельницького: «А я ляхів не боюся. / І гадки не маю - / За собою великую / Потугу я знаю, / I ще й орду татарськую / За собой веду, - / А все тото, вражі ляхи, / На вашу біду» [УНД 1955: 92]. При створенні цього фольклорного образу не втрачається відчуття художньої міри, не розривається зв'язок 3 історичним прототипом, а зберігаються самобутні риси його характеру. Ці твори далекі од копіювання історичних подій, вони широко використовують поетичний арсенал, традиційні засоби героїчного епосу, що дозволяють створити всебічну характеристику героя. Звісно, характеристика героїв та їх дій, відтворених у піснях, не завжди повністю відповідають фактичній історії козаччини, оскільки «історик не повинен шукати в них сказання дня і числа битви або точного пояснення місця, вірної реляції; з цього погляду небагато пісень допоможе йому. Та коли він захоче віднайти вірний побут, стихії характеру, всі вигини й відтінки почуттів,

1 Українські народні думи та історичні пісні / За ред. М.Т.Рильського та К.Г.Гуслистого. - К.: Вид. АН УРСР, 1955. - С.92 
хвилювань, страждань, веселощів зображуваного народу, коли захоче випитати дух минулого віку, загальний характер всього цілого й порізно кожного окремого, тоді він буде задоволений цілком; історія народу розкриється перед ним у ясній величі» [Гоголь 1952 : 394]. В них народ дає волю своїй творчій фантазії, художньому вимислу, а тому «історизм цих пісень полягає не в тому, що в них правильно виведені історичні особи і розказані історичні події або такі, які народ вважає дійсними. Історизм їх полягає в тому, що в цих піснях народ висловлює своє ставлення до історичних подій, осіб і обставин, виражає свою історичну самосвідомість. Історизм тут $є$ явище ідейного порядку» [Пропп 1998: 190].

В умовах постійної й запеклої боротьби українського народу проти турецько - татарського, польського й московського поневолення, саме запорозькі козаки-бандуристи, кобзарі як носії народної пам'яті широко розносили славу про подвиги хороброго лицарського товариства по всьому світу. Творці козацького пісенного фольклору дуже обережно поводилися з їх змістом, а тому не насмілювалися «домальовувати» образ козака шляхом художнього домислу, або свідомо перебудовувати сюжет за рахунок фактів історії.

\section{БІБЛІОГРАФІЯ}

Возняк 1994 - Возняк М.С. Історія української літератури: У двох книгах

/М.Возняк. - Львів, 1994. - Кн. Друга. - 560 с.

Гоголь 1952 - Гоголь М. Твори в трьох т. /М.Гоголь. - К., 1952. - Т.3. - С. 393-400.

Колесса 1935 - Колесса Ф. Формули закінчення в українських народних думах у

зв'язку з питанням про наверстування дум /Ф.Колесса. - Львів, 1935.

Костомаров 1880 - Костомаров Н. История казачества в памятниках южнорусско-

го народного песенного творчества /Н. Костомаров // Русская мысль, 1880. -

Кн. .№1.

Пропп 1998 - Пропп В. Поэтика фольклора /В.Пропп. - М.: Наука, 1998.

СПП 1985 - Соціально-побутові пісні ; упор., вступ. стат. та примітки

О.М.Хмілевської. - К., 1985.

УНД 1955 - Українська народна творчість. Історичні пісні. - К. : Вид. Ан УРСР, 1961. $-1067 \mathrm{c}$.

Яременко 1970 - Яременко В. Народні думи, пісні, балади /В.Яременко ; вступ.

стаття, упоряд. текстів та примітки В.Яременка. - К., 1970.

Стаття надійшла 10 листопада 2013 р. 